\title{
COLETIVO PIXOTE INTERVÉM: O TEATRO DO OPRIMIDO E A SOCIOEDUCAÇÃO
}

COLETIVO PIXOTE INTERVIENE: EL TEATRO DEL OPRIMIDO Y LA SOCIOEDUCACIÓN

Carla Dameane Pereira de Souza*

RESUMO: Neste artigo apresento a experiência do Coletivo Pixote ao longo do desenvolvimento do projeto de extensão "Pixote intervém: ẫes colabortivas junto à Fundaça da Criança e do Adolevem: aços coll") cente cicina . prenadas pelos principios do Teatro do Oprimido (TO). A proposta foi

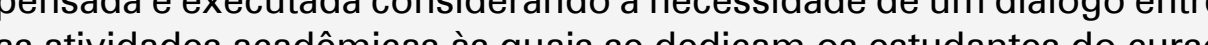
de Letras/Espanhol a milina e La performano âmito da socioeducão Para tanto, utilizarios insumes térices de Cynthia Bisino to al. (2015), Augusto Boal (2009, 2015) M (2015). Fina Lima "Muniz (2015), Angela " (2015). Finalmente, farei a exposiçao dos "reafectos criativos", isto é, das reaçoes que pantindo de una convivencia afetiva durante as ofici-

PALAVRAS-CHAVE: Socioeducação; Teatro do Oprimido; Improvisação; Direitos Humanos.

\author{
* carladameane@gmail.com \\ Doutora em Letras: Estudos Literários. Instituto de Letras da \\ Universidade Federal da Bahia.
}

RESUMEN: En este articulo presento la experiencia del Colectivo Pixote durante el desarrollo del proyecto de extensión "Pixote intervém: ações colaborativas junto à Fundação da Criança e do Adolescente (FUNDAC)" deracendo ecional en el contexto de la socioeducación a partir de la realización de talleres de creación artísticas interdisciplinares de la Lengua Española, orientadas por los fundamentos del Teatro del Oprimido (TO). proy octo fue pero lo $y$ ejecutado considerando la neceside (T). diálogo fue pensado y ejecutadón estudiantron los de la práctica teatral y performática en lámbito de la socicada a través Para ello, utilizaré los aportes teóricos de Cynthia Bisinoto et al. (2015) Augusto, unz (2009, 2015), Marian Lim Muniz (2015), Angela (2015), (2016) y Judith Butler (2015). Finana Lima Muniz (2015), Angela Davis (2016) y Judith Buller (2015). Finalmente, hablare de "reacciones creativas", es decir, las reaciones que partiendo de la convivencia afectiva

PALABRAS-CLAVE: Socio ción; Derechos Humanos. 
1. Fragmento de Kilates, (2016), ação cênica do Coletivo Pixote. Este fragmento pertence a Manue Manu, uma jovem vendedora ambulante. A composição desta presença foi inspirada diretamente em relatos informais de jovens reinseridos à sociedade após a experiência da privação de liberdade e foi encenada por Jade Bittencourt, que faz parte do Coletivo e a quem agradeço por ter feito a tradução de partes deste

texto, inicialmente redi

\section{A COMUNIDADE UNIVERSITÁRIA E A}

\section{SOCIOEDUCAÇÃO: PRIMEIROS CONTATOS}

Eu devia tá roubando, eu devia tá matando. Eu devia tá subindo e descendo as ladeiras do morro com uma garrafa de São Jorge em uma mão e uma pistola .40 na outra. Eu devia não ter jeito, nem ter nascido. Mas sou e estou por insistência minha. Experimenta negar minha existência. Experimenta tapar com tarja preta minha condição de menor abandonado pelo Estado que quer me tutelar pra fabricar soldado com prazo de validade 18. Tenta tapar com tarja preta meu olhar que te encara. Sou e estou por insistência minha. Meu banzo agita o que eu sou. Tenho kilates de sobrevivência. Não sei onde colocar a vírgula, tá ligado? Mas sei contar a minha história e assino embaixo.

Em um agosto do ano de 2013 deixei Minas Gerais, estado onde nasci e me formei como professora de Língua Espanhola e me mudei para a Bahia, estado da região nordeste do Brasil. Meu destino era Salvador, a primeira capital do Brasil, onde atualmente vivo e trabalho como professora no Instituto de Letras da Universidade Federal da Bahia (UFBA). Cumprindo esta função me aproximei do universo da socioeducação sem conhecer, a princípio, o que era e como funcionava.

Segundo Bisinoto et al. (2015), no artigo "Socioeducação: origem, significado e implicação para o atendimento socioeducativo" (2015), a socieducação deve ser entendida a partir de uma prática de educação com forte cunho social e está:

[...] pautada na afirmação e efetivação dos direitos humanos, com compromisso com a emancipação e autonomia de cada sujeito em sua relação com a sociedade. A socioeducação se orienta por valores de justiça, igualdade, fraternidade, entre outros, tendo como objetivo principal o desenvolvimento de variadas competências que possibilitem que as pessoas rompam e superem as condições de violência, de pobreza e de marginalidade que caracterizam sua exclusão social. ${ }^{2}$

Conforme os autores nos explicam, a socioeducação não é uma prática específica de diretrizes socioeducativas para adolescentes e jovens que respondem por atos infraciona is. Porém, eles ressaltam que é neste contexto em que o termo adquire visibilidade, ao considerarem que "a socioeducação deve se traduzir em práticas e intervenções consistentes, efetivamente promotoras de conquistas e transformações nas trajetórias de desenvolvimento das pessoas, dentre os quais, e especialmente, os adolescentes autores de atos infracionais. ${ }^{3}$ Embora as pesquisas bibliográficas nos ajudem a compreender o funcionamento da socioeducação, teoricamente, só após a prática, atuando diretamente com os
2. BISINOTO et al. Socioeducação: origem, significado e implicaçoes para $o$ atendimento socioeducativo, p. 581-582.

BISINOTO et al. Socioeducação: origem, significado e para $o$ atendimento socioeducativo, p. 581-582.

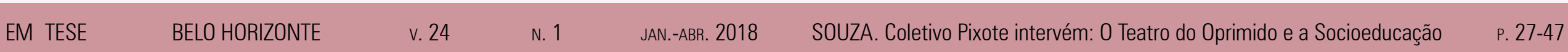


sujeitos envolvidos, é que essa concepção de educação social começa a fazer sentido.

Ao participar de uma ação voluntária para a preparação de adolescentes que se encontravam em privação de liberdade, cumprido medidas socioeducativas, não pensei que esse breve contato tornar-se-ia o ponto de partida para uma série de questionamentos sobre a educação social de modo geral e, de modo particular, sobre a minha prática como professora que forma futuros professores de Língua Espanhola, mas que, inicialmente, não estive atenta a este campo de atuação que é a docência para adolescentes e jovens que se encontram em situação de privação de liberdade, isto é, a docência em contexto socioeducativo. A preparação acima mencionada consistia em um conjunto de aulas de diferentes disciplinas curriculares para que os adolescentes assistidos pela Fundação da Criança e do Adolescente do Estado da Bahia - FUNDAC pudessem alcançar bons resultados no ENEM PPL (Exame Nacional do Ensino Médio para Pessoas Privadas da Liberdade).

Dura nte o evento denominado "Aulão do Enem" que reuniu adolescentes que estavam sob regime de privação de liberdade nas diferentes Comunidades de Atendimento Socieduca tivo (CASE) assistidas pela FUNDAC pude, pela primeira vez, conhecer o funcionamento das atividades formativas da socioeducação no segmento de proteção tutelar que atende aos jovens e adolescentes que infringem a lei. Nestes dias, me cha mou atenção, especialmente, as atividades artísticas que os jovens apresentaram antes das aulas começarem. Não só os rapazes, mas também as poucas adolescentes mulheres que ali estavam se apresentaram cantando, recitando poemas e encena ndo situações cotidianas, sobretudo, no que se refere às campanhas preventivas associadas à saúde da mulher e do homem; eram cenas curtas com apelo pedagógico.

Antes e depois de ter dado minhas aulas de Língua Espanhola, explorando os conteúdos programáticos previstos, fiz algumas perguntas às assistentes sociais e pedagogas, presentes no evento, sobre a possibilidade de estabelecermos parcerias e elas me disseram que a oferta de oficinas de arte-educação seria bem acolhida pelo Setor Pedagógico da Instituição. Como na universidade eu já tinha uma equipe de três jovens que pesquisavam sobre estudos da performance, lhes propus fazermos um experimento e junto à Coordenadora Pedagógica da FUNDAC Maria Mercedes Agrícola Bomsucesso, pla nejamos uma ação de extensão a qual chama mos "2a Vigília Informativa por Ayotzinapa: Ações colaborativas na Comunidade de Atendimento Socieducativo - CASE Cia”, localizada no município de Simões Filho. A ação de extensão realizou-se entre os dias 16 e 19 de dezembro de 2015 
5. Participaram do projeto: Carlos Alberto Medeiros, Jade Oliveira Bittencourt das Virgens, José Hernani Santos (Zezé Olukemi), Kellen Hawena Pereira Sousa, Lindyana Jesus dos Santos, Louise Cristina dos Santos Queiroz, Monique Santos Neiva e Tereza Pereira. São colaboradores do Coletivo: Evanilton Gonçalves, Miracleia de Souza Saldanh (Mirapotira), Cintia Salviano (Merreira (Clntia Savoli) (Colectivo Rima Mina) e Maicon Sulivan. Gomes (fotógrafo), Mauricio dos Santos Souza, Mr. Armeng MC Ravi Lobo, MC Moreno, Dj Cabeça (Rap Nova Era) e Dj Gug.

4. Embora este artigo tenha sido escrito por mim, e, portanto, o apresento usando a primeira pessoa do singular, como parte de um Coletivo, passarei a unilizar a primeira pessoa do plural na decisóes que foram tomadas pelo grupo ou fatos que vivenciei em
É importante ressaltar que durante a elaboração das primeiras ações nós ${ }^{4}$ decidimos nomear o coletivo ${ }^{5}$ com o nome do personagem do livro A Infância dos Mortos (1977), de José Loureiro e em homenagem ao filme Pixote, a lei do mais fraco (1980), de Héctor Babenco, tão importante para pensar nos direitos das crianças e dos adolescentes no Brasil em um contexto histórico anterior à existência do Estatuto da Criança e do Adolescente (ECA). As oficinas foram realizadas com a colaboração da FUNDAC e também da Pró-Reitoria de Extensão da Universidade Federal da Bahia (PROEXT/UFBA). Sobre nossa metodologia, seguimos as diretrizes do Sistema Nacional de Atendimento Socioeducativo - SINASE e as propostas pedagógicas da FUNDAC, que compreendem a educação formal, a educação artística e a educação profissional dos jovens assistidos por ela.

A primeira Vigília Informativa tinha sido realizada em novembro de 2014, quando, a fetados pelos acontecimentos ocorridos em Ayotzinapa (México) organizamos uma Vigília em memória e protesto pelo desaparecimento dos 43 estudantes em 26 de setembro de 2014. O contexto em que discutimos o caso Ayotzinapa na UFBA teve a ver, primordialmente, com a necessidade de informar aos jovens soteropolitanos, estudantes da instituição, sobre o ocorrido em Ayotzinapa e fazê-los refletir sobre de que modo estes eventos de violência e crimes contra os Direitos Humanos que acontecem no México são parecidos com os atos de violência que vivem, diariamente, os jovens brasileiros, principalmente, os jovens negros e pobres do Brasil. ${ }^{6}$ Apesar do fato de o Brasil se localizar no continente latino-a mericano, nossos estudantes sabem pouco sobre o que ocorre nos demais países da América Latina e a Vigília Informativa cumpriu a tarefa de fazer circular a informação e promover o debate. Ao mesmo tempo, convidamos familiares de adolescentes desaparecidos na cidade de Salvador, durante ações policiais, para participar do evento. Desta maneira, a jovem Camila Fiúza, irmã de Davi Fiúza, menor desaparecido depois de ser detido pela Polícia Militar de Salvador/ BA, deu seu testemunho sobre o desaparecimento de seu irmão e a permanente luta de sua família por justiça. ${ }^{7}$

Em 2015, quando propusemos a $2^{\text {a } V i g i ́ l i a, ~}{ }^{8}$ tínhamos uma expectativa pouco nítida sobre como trabalhar com adolescentes e jovens em situação de privação de liberdade, por isso, a segunda experiência do Coletivo Pixote com a socioeducação, em 2016, foi diferente da $2^{\text {a Vigília }}$ Informativa por Ayotzinapa: Ações colaborativas na CASE Cia. Ainda que a proposta de realização de oficinas interdisciplinares de Língua Espanhola tenha se mantido, o projeto inicial sofreu alterações em sua metodologia e equipe. Com o projeto "Pixote intervém: ações colaborativas junto
6. As investigações realizadas pelo Instituto de Pesquisa Econômica Aplicada (IPEA) e pelo Fórum Brasileiro de Segurança Pública (FPSP), divulgados no Atlas da Violência de 2017, apontam que "De cada 100 pessoas que sofrem homicídio no Brasil, 71 são negras. Jovens e negros do sexo masculino continuam sendo assassinados todos os anos como se vivessem em situação de guerra" (Cerqueira et al. 2017, p. 30). Ainda segundo o Atlas, em 2015 a taxa de homicídios por 100 mil habitantes negros, no Estado da Bahia foi de 45,0 e a taxa de homicídios por 100 mil habitantes náo negros foi de 12,0 . Conferit:

7. É possível obter informações mais detalhadas sobre este tema na pagina da Anistia Internacional do Brasil. Disponível em: <https:// anistia.org.br/noticias/policiacivil-conclui-inquerito-sobredesaparecimento-forcado-de-davifluza indiciando-23-policiais/>.

8. Refiro-me à $2^{\mathrm{a}}$ Vigília Informativa por Ayotzinapa: Ações colaborativas na CASE Cia (Simões Filho), realizada entre os dias 16 a 19 de dezembro de 2016, na Comunidade de Atendimento Socioeducativo de Simões Filho - CASE Cia.

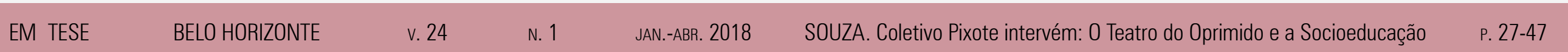


a Fundação da Criança e do Adolescente (FUNDAC)" intervimos em três CASE diferentes: a CASE Irmã Dulce, em Camaçari, a CASE Zilda Arns, em Feira de Santana e a CASE Salvador, a mpliado o campo de atuação e reconhecendo novos adolescentes que nos provocaram, a cada oficina, a repensar nossa prática naquele contexto.

Ao sair da universidade, para fazer extensão, os estudantes de Letras estabelecem um diálogo direto com a comunidade externa e se sentem motivados por poder ampliar o contexto de sua militância e ativismo, já que, como coletivo (e aqui me incluo) não apoia mos a redução da menor idade penal e lutamos pela educação básica de qualidade. Por isso, estou chamando de militância aplicada a possibilidade de pesquisadores acadêmicos atuar junto à organizações ou entidades socia is, governamentais ou não governamentais que lhes garanta a aplicação dos seus conhecimentos teóricos aos práticos em defesa ou relacionados aos Direitos Humanos. Essa militância está associada, por sua vez, ao ativismo crítico, que, para mim, é a atuação de acadêmicos na esfera pública, não só através de sua produção bibliográfica, mas no que diz respeito à sua atividade física no campo cultural, acompanhando e dialogando com os movimentos sociais que defendem as causas pelas quais milita e, portanto, agem criticamente - refletindo as contradições produzindo conhecimentos e difundindo os processos vivenciados como resultados parciais.
No que se refere ao planejamento das atividades, ao mesmo tempo em que pareciam motivadoras, era grande a insegurança em relação ao público da ação que exigiu de nós uma atenção especial. Este planeja mento deveria prever a instabilidade do funciona mento das Comunidades de Atendimento Socioeducativo - CASE, no que se refere à rotina de acolhimento e liberação dos adolescentes, ao fa to de que os adolescentes possuem níveis de escolaridade distintos, de modo que a metodologia de trabalho deveria atender a esses distintos níveis para que todos participassem e, ainda, ao fato de que nem sempre os adolescentes estavam dispostos a corresponder às atividades planejadas.

Ocupar estas CASE significava pôr nossos corpos e olhares em direção a um horizonte pouco percebível por nós, enquanto sociedade, que vemos o adolescente e jovem infrator, muitas vezes, a partir de crenças que em nada o auxiliam em sua recuperação e posterior reinserção; ao contrário, as crenças fazem com que sua condição de excluído mantenha-se com a justificativa de que não deve ser acolhido devido ao ato ou histórico de atos infracionais.

O projeto de ocupação eventual das CASE tornou possível uma percepção mais abrangente dos sujeitos ali imersos, considerando não só os adolescentes e jovens, como também todo o corpo de funcionários que atuam no sistema socioeducativo. Assim, foi possível reconhecer sujeitos e

EM TESE BELO HORIZONTE $\quad$ v. $24 \quad$ N. $1 \quad$ JaN.ABR. 2018 SOUZA. Coletivo Pixote intervém: 0 Teatro do Oprimido e a Socioeducação $\quad$ P. 27-47

\section{Dossiê}


9. BUTLER. Quadros de Guerra. Quando a vida é passível de luto?, p.14.

10. BUTLER. Quadros de Guerra. Quando a vida é passível de luto?, p.23.

11. BUTLER. Quadros de Guerra. Quando a vida é passível de luto?, p.14

12. IPEA. 2015 , p. 15 espaços que a sociedade "enquadra", no sentido em que propõe Judith Butler (2015), qua ndo diz que o enquadramento diz respeito a que "as molduras pelas quais apreendemos ou, na verdade, não conseguimos apreender a vida dos outros como perdida ou lesada (suscetível de ser perdida ou lesada) estão politicamente saturadas". ${ }^{9}$ No entanto, Butler também nos diz, recordando Trinh Minh-há, que é possível "enquadrar o enquadra mento" ou "o enquadrador", ${ }^{10}$ processo que se refere a dar visibilidade ao efeito ou conceito que culpabiliza aquele que está sob o enquadra mento. "Enquadrar o enquadra mento", segundo Butler, ${ }^{11}$ é questionar a moldura.

A moldura a que me refiro, alundindo ao contexto da socioeducação, diz respeito ao imaginário que se reproduz das CASE como lugares de "castigo", "exclusão social" e "racismo" e do jovem e do adolescente autor de atos infraciona is como sujeito "perigoso" e "incorrigível". Essa visão se baseia no fato de que o adolescente e o jovem que cumprem medidas socioeducativas possuem um perfil emoldurado por sua condição étnica e de classe e está a travessada pelo racismo estrutural que caracteriza nossa sociedade e que, por isso, o enquadra como indivíduo que representa a meaça. Segundo os estudos do Instituto de Pesquisa Econômica Aplicada - IPEA, ${ }^{12} 95 \%$ desses adolescentes e jovens que cumprem medidas socioeduca tivas são negros e $66 \%$ vivem em fa mílias extrema mente pobres. Ainda segundo este documento

Estimativas do UNICEF Brasil, com base em dados do levantamento SINASE (2012) e da PNAD/IBGE (2012), destacaram que, dos 21 milhões de adolescentes que vivem no Brasil, menos de meio por cento $(0,013 \%)$ cometeu a tos contra a vida, isto é, cumpriam medidas socioeducativas de privação de liberdade por atos análogos a homicídio, latrocínio, estupro e lesão corporal. Apesar de alguns adolescentes estarem cometendo atos reprováveis, a maioria das informações disponíveis dão conta de que um conjunto expressivo dos jovens estão desprotegidos das políticas públicas e dos direitos socia is básicos e são, ainda, vítimas de violência, e não autores, conforme grande parte da sociedade acredita. ${ }^{13}$

Considera ndo as CASE como luga res de "exclusão" onde os adolescentes e jovens que cumprem medidas socioeducativas são reclusos de um convívio social anterior já caracterizado pela vulnerabilidade econômica e pela violência, nos questionamos sobre de que forma estas comunidades podem se tornar espaços de educação para que os adolescentes e jovens saiam dali conscientes de que seus atos infracionais são consequências de uma violência que é estrutural, que é parte de um sistema opressor possível de enfrentar sem reagir devolvendo a violência pela qual são
13. SILVA; OLIVEIRA. O Adolescente em Conflito com a Lei e o
Debate sobre a Redução da Maioridade Penal: esclarecimentos necessários, p.13.

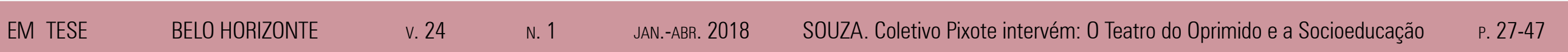


14. SILVA; OLIVEIRA. O Adolescente em Conflito com a Lei e o Debate sobre a Redução da Maioridade Penal: esclarecimentos necessários, p.13.

15. Estou considerando que a partir da privação da liberdade devido da privaçáo da liberdade devido destituídos do convívio familiar, pois ficam sob a tutela do Estado. Embora com direto à visita são monitorados em tempo integral e seguem uma disciplina que modifica rotinas e hábitos anteriores. Os adolescentes e jovens são privados de uma das fases mais importantes de sua vida em que podem passear com amigos, experimentar a transformação do próprio corpo e da intimidade, namorar, fazer planos. A privação de liberdade mita a experiência do sujeito com a adolescência.

16. BOAL. O teatro como arte marcial p.173-174. afetados. Conforme a citação de Silva e Oliveira, estes jovens precisam entender que são "vítimas de violência e não autores", ${ }^{14}$ ao invés de, como muitos fazem, apropriar-se do poder de "atuar violentamente" como forma de autoproteção e imposição de uma postura que deseja afastar o outro, ao invés de mantê-lo por perto.

$\mathrm{Na}$ medida em que decidimos, como coletivo, ocupar e falar desde dentro das comunidades de atendimento aos adolescentes e jovens que cumprem medidas socioeducativas, assumimos este lugar como um espaço de educação social, sem deixar de vê-lo como um lugar de castigo. ${ }^{15}$ Desse modo, os projetos desenvolvidos pelo Coletivo Pixote, têm como principal objetivo reconhecer os jovens e tudo o que está "enquadrado" no que diz respeito ao seu ingresso e perma nência nas CASE, ao mesmo tempo em que os estudantes e outros profissionais que colaboram com o coletivo têm a oportunidade de rever sua prática profissional na socioeducação. O que orienta o Coletivo é a possibilidade de questionar a moldura, desde o interior desta moldura desde o espaço onde os adolescentes e jovens se enunciam.

\section{A RECOPILAÇÃO DOS AFETOS ATRAVÉS DO TEATRO} DO OPRIMIDO

Aprendemos com Augusto Boal ${ }^{16}$ que o trabalho com o Teatro do Oprimido $(\mathrm{TO})^{17}$ está embasado em cinco postulados principais que sustentam sua dimensão filosófico-humanista:

Trabalha mos com os oprimidos - cidadãos dos quais se tira o direito à palavra, ao diálogo, a seu território, a sua livre expressão, a sua liberdade de escolha -, com os quais nos identificamos, sentimos analogias ou intensa solidariedade.

Queremos ajudá-los a recuperar sua linguagem teatral, linguagem humana por excelência, geralmente perdida depois da infância. Buscamos a difusão no nosso método estético entre todos os oprimidos, buscamos a multiplicação e não o limitado consumo individual.

Queremos ajudá-los para que se transformem de espectadores passivos, na vida e no teatro, em protagonistas, no tea tro e na vida.

No presente, o TO ajuda a seus praticantes a analisar o passado em linguagem teatral, para que possam inventar o futuro. $\mathrm{O}$ TO busca transformar a realidade, não apenas compreendê-la e, renegando, lamentá-la.

Desejamos promover a educação estética dos oprimidos, pois o ato de transformar é transformador: desejamos desenvolver as capacidades artísticas e estéticas dos participantes, inclusive das artes teatrais, além da obra de arte.
17. Para expor de modo sintético, reproduzo a apresentaçăo de Muniz $(2015$, p. 92) sobre o Teatro do Oprimido. Em suas palavras O Teatro do Oprimido surgiu a partir das vivencias com o teatro popular e didático que Boal teve tanto do CPC quando no Teatro Arena, e em seu exílio, ampliou suas perspectivas ao entrar em contato com a realidade do povo latino-americano, começando a sistematizar as premissas históricas e técnicas de seu teatro. Segundo o dramaturgo brasileiro, para que se é necessário levar em conta seu principal objetivo: transforma povo "espectador", ser passivo no fenômeno teatral, em sujeito, em ator, em transformador da ação dramática."'" No que se refere ao campo da improvisação diante do público, Muniz destaca as seguintes técnicas em seus estudos: "o Teatro Jornal, o Teatro Invisível, o Teatro Fórum e o Teatro Legislativo" (2015, p. 96).

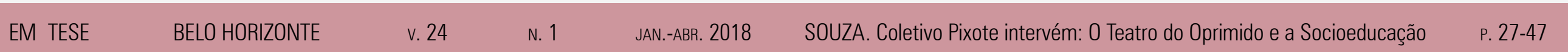


18. Importante sinalizar a participação de Anativo José Oliveira Silva socioeducador da FUNDAC, responsável pela área de Artes Cenicas, durante a realização das ficinas de Teatro do Oprimido.

19. MUNIZ. Improvisação como espetáculo. Processo de criação e metodologias de treinamento do ator-improvisador, p.24.

20. Também a noção de jogos teatrais, de Viola Spolin (2007), foi inspiradora, como procedimentos metodológicos na sala de aula. Assim como os jogos para atores e não autores de Augusto Boal, os jogos teatrais de Spolin alcançam sentido prático para os jogadores que, enquanto jogam brincam aprendem e pensam sobre aspectos da vida.
Inspirados e orientados por tais postulações, de modo geral, o projeto sobre o qual relato propunha uma abordagem interdisciplinar nas três oficinas oferecidas: a Oficina de Teatro, ${ }^{18}$ a Oficina de Freestyle e a Oficina de Graffite. Nas três oficinas um elemento comum, a improvisação, foi determinante para que alcançássemos êxito, o que significa motivar o adolescente a participar tanto ativamente quanto como observadores. Conforme Mariana Lima Muniz, 19 "só existe cena porque o público está ali observando. Observar é um verbo e, portanto, uma ação. É para o público que o tea tro improvisado é criado" e nas demais oficinas realizadas, não somente a de Teatro, a improvisação esteve presente uma vez que a produção artística se desenvolvia através do diálogo - no caso das oficinas de Graffite; através da improvisação musical, no caso das oficinas de Freestyle, e nas oficinas de Teatro, por meio dos jogos adaptados a partir do livro Jogos para atores e não atores (2015) de Augusto Boal. Estes jogos, além de quebrar a formalidade no início de cada oficina, associados também à metodologia dos jogos teatrais, ${ }^{20}$ de Viola Spolin (2007) funcionava $\mathrm{m}$ como pontos de partida para o estabelecimento de diálogos, para que os participantes pudessem ocupar o espaço da cena com outro corpo, preparado crítico, em relação ao indivíduo que é ou em busca de reconhecer-se como sujeito, sem os enquadra mentos aos quais estão submetidos.

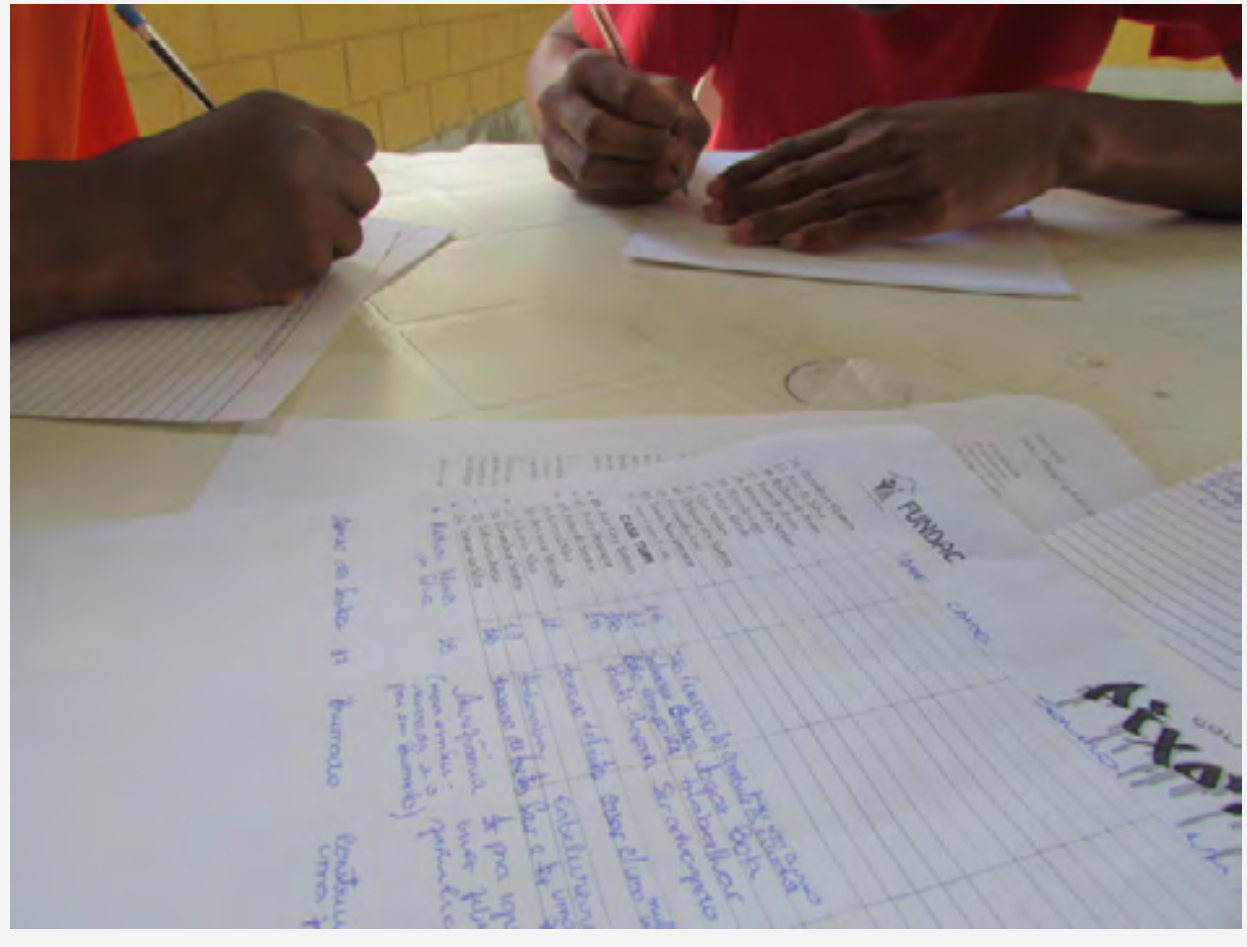

FOTOGRAFIA 1

Durante a realização das oficinas de Teatro do Oprimido percebi que, se o cárcere e a situação de privação de liberdade imobilizam as atitudes físicas e intelectuais dos jovens que transgridem a lei, o teatro, como ressalta $\mathrm{Boal}^{21}$ é capaz de ativar a criação e mobilizar estes jovens diante de situações nas quais eles "decidem, inventam e assumem uma forma de poder: sua inteligência e sua criatividade", ${ }^{22}$ como apresentarei a seguir. Já nas oficinas de Freestyle: ritmo e poesia, os jovens foram estimulados a criar textos
FOTOGRAFIA 1 Adolescentes na Oficina de Grafite. CASE Irmã Dulce, Camaçari, Bahia Brasil. 18 de agosto de 2016. Foto de Lindy Santos.

21. BOAL. O teatro como arte marcial, p.180.

22. BOAL. O teatro como arte marcial, p.180.

EM TESE BELO HORIZONTE $\quad$ v. $24 \quad$ N. $1 \quad$ JAN.-ABr. 2018 SOUZA. Coletivo Pixote intervém: 0 Teatro do Oprimido e a Socioeducação $\quad$ P. 27-47


23. CAMARGOS. RAP e política. Percepções da vida social Percepçoes da vida
brasileira, p. 130. poéticos ritmados a partir de estímulos sensoriais: textos, imagens, sons, mas acima de tudo, a partir de sua própria memória e experiência, acompanhados pelos beats, fundo musical para a improvisação. De modo espontâneo, eles praticavam as teorias da criação literária e musical, sem que estas fossem transmitidas a eles de modo formal. Isso foi possível porque

As tensões das relações sociais se encarnam na linguagem rap e projetam a produção cultural como uma memória seletiva de aspectos do trabalho, da política, dos costumes, dos símbolos e valores do emaranhado que é a sociedade contemporânea. É possível pensar essas músicas como portadoras de elementos constituintes das constantes mudanças sociais, como um campo de luta em que as disputas de domínio e afirmação se fazem presentes. ${ }^{23}$

Como grande parte dos adolescentes e jovens que participaram das oficinas gosta de Rap, expressar-se através deste gênero musical foi uma maneira de narrar os conflitos que viviam antes da vida no cárcere, marcados por distintos tipos de traumas associados a comportamentos infracionais ou a situações de opressão fa miliar. Na rravam a vida dentro das CASE, marcada pela vigilância e prescrições socioeducativas, mas ta mbém pelos conflitos que há entre eles mesmos, entre um jovem e outro, entre grupos de jovens. Porém, o mais interessante era qua ndo a poesia ritmada tratava de projetar um futuro de liberdade ou uma reflexão sobre a sua própria condição, como vemos na improvisação do adolescente Daniel ${ }^{24}$ que cumpria medida socioeducativa na CASE Zilda Arns, em Feira de Santana:

Essa voz não é minha direção

onde o medo, o preconceito e desconfiança

história cabulosa manchou o meu coração

não aguentava mais ver minha família chorando

e bati na viagem do crime

não resisti.

Assalto à joalheria, sequestro e roubo a banco

por que a sociedade tá com medo de mim

se ela me fez assim?

Sempre eu preservei minha honestidade

até que o ódio tomou o espaço do meu coração

No meu inconsciente eu meu perguntei:

eu sou da luz da escuridão?

Por favor, diz o que eu sou!

Um mensageiro de Deus?

Um assassino cruel?

Um guerreiro dos céus?

Opiniões eu divido

tudo pelo simples fato

de eu nascer favelado. ${ }^{25}$

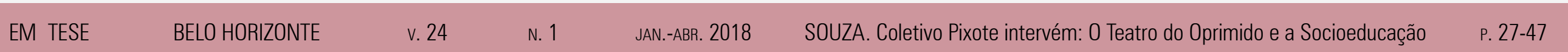


26. MUNIZ. Improvisação como espetáculo. Processo de criação e metodologias de treinamento do ator-improvisador, p.94.
Nessas narrações improvisadas, os processos de opressão vividos por cada um são elaborados livremente. No Rap improvisado de Daniel, há nuances de sua subjetividade acompanhada por questionamentos que dizem respeito a sua consciência como indivíduo que sabe que sua condição de infrator é de responsabilidade da sociedade a qual pertence, e que dele sente medo. O "simples fato de ser um favelado" é a mplificado nas perguntas sobre quem ele é, "um mensageiro de Deus ou um assassino cruel?”. Entendo que esta seja uma reflexão inserida na performance do sujeito que, enquanto conta-nos sobre quem é, o faz como forma ta mbém de compreender a si mesmo, por que sendo apenas um jovem rapaz, é também capaz de causar temor e agir de forma violenta? Em consonância com os princípios do Teatro do Oprimido nas oficinas de criação musical, os adolescentes eram desafiados a improvisar sobre temas prévios ou sobre o que gostariam de falar, corroborando com a descrição que Muniz faz dele e de sua relação com a improvisação:

Por suas próprias características - a escuta do grupo e a construção de uma história contada no calor da ação, no momento presente -, a improvisação é uma ferramenta importante para os propósitos do Tea tro do Oprimido, pois possibilita o reconhecimento prático de seus conflitos e a apropriações de soluções que podem ser representadas imediatamente para posteriores discussões, reformulações, abrindo-se para novas possibilidades. ${ }^{26}$
Reflexões que eram destaque nas oficinas de Freestyle podiam reaparecer nas oficinas de Teatro do Oprimido por sugestão dos adolescentes ou quando a linguagem do RAP espontaneamente ocupava um lugar na cena. Quando os MCs Ravi Lobo e Moreno do Grupo de Rap Nova Era, estiveram na CASE Salvador para fazerem um show, a convite do Coletivo Pixote, participaram de uma das oficinas de Teatro do Oprimido. Naquela oficina, uma das improvisações que realizamos, no contexto do Tea tro Fórum, ${ }^{27}$ teve como ponto de partida o relato de MC Ravi Lobo sobre uma abordagem policial vivida por ele. A história foi dirigida e encenada por adolescentes, pelos funcionários da CASE e por membros do Coletivo Pixote. Os jovens expressaram o que pensaram sobre a situação encenada, buscando outros caminhos que não o da violência, para solucionar o conflito. Neste caso, como reagir diante do abuso policial em abordagens de rotina? Quando o Curinga ${ }^{28}$ abriu espaço para os adolescentes construírem a cena e nela intervirem, apresentando a sugestão de uma resolução para o conflito, deram destaque à mãe, que na improvisação foi encenada por uma socioeducadora e ao advogado que, encenado por um adolescente, foram as duas vozes que interviram em favor do personagem que após sofrer a abordagem abusiva e reagir, fora apreendido.

As improvisações também foram trabalhadas junto às performances e ações cênicas que o Coletivo criou para serem apresentadas aos adolescentes e jovens e, a partir
27. De acordo com Boal $(2015, \mathrm{p}$. 293), ao longo das pesquisas feitas sobre o Teatro Fórum no Brasil e em outros países, conceitos, estruturas, técnicas e processos já passaram por revisões contextuais Porém, para ele os princípios mesmos do Teatro Fórum são "1) a transformação do espectador em protagonista da ação teatral e, atraves dessa transformação 2) a tentativa de mudar a sociedade $e$ não apenas interpretá-la".

28. O Coringa no Teatro Fórum é, segundo Boal (2015, p. 303) o "mestre de cerimônia do espetáculo-fórum". No que diz respeito a sua conduta, ele atua como um mediador devendo, pois, "evitar todo tipo de manipulação, de indução do espectador, năo deve tirar conclusões que não sejam evidentes. Deve questionar sempre as proprias conclusões e enunciá-las em forma de pergunta, e não afirmadamente, de forma que os espect-atores tenham que responder sim ou não, $[. .]>.>>$

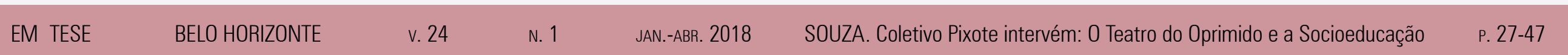


28. > > > não decide nada por conta própria. Enuncia as regras do jogo, mas, a partir daí, deve aceitar até mesmo que a plateia as modifique, se isso for julgado conveniente para o exame do tema em questão. [...] deve constantemente reenviar as dúvidas a plateia para que ela decida. Vale ou não vale? É certo ou errado? Especialmente no que diz respeito às intervenções dos espect-ator, muitas vezes quando alguém grita "Para!" quando o espect-ator precedente ainda nâo terminou sua ação - o Coringa deve fazé-lo esperar que o primeiro ermine de mostrar a açá qué s popos, nas deve ser sésive ter entendido a ac̃o proposta preferindo passar adiante." delas, estabelecermos diálogos nos quais que eles pudessem conosco compartilhar suas impressões sobre as experiências em mostras e falar sobre suas próprias experiências. $\mathrm{Na}$ ação cênica Kilates, criação do Coletivo Pixote, uma situação é apresentada através da presença de cinco sujeitos que enfrentam contextos visíveis de opressão (uma gari, um morador de rua, uma adolescente vendedora a mbulante, um desempregado e uma mulher que procura seu filho desaparecido) e a presença de uma senhora que utiliza seus privilégios de classe para entabular com estas cinco presenças uma situação de diálogo muito tensa sobre violência, dignidade e Direitos Humanos.

A encenação de Kilates nas CASE de Feira de Santana e Camaçari foi possível graças ao número reduzido de adolescentes e jovens liberados para a oficina de teatro, o que garantia a realização dos demais jogos programados. No entanto, como tínha mos que atender um número maior de jovens na CASE Salvador, decidimos construir uma performance curta. Jade Bittencourt e eu cria mos uma performance inspirada nas histórias que os jovens nos contavam de modo informal durante nossas intervenções e também na obra Memorias de un soldado desconocido. Autobiografía y antropología de la violencia, (2014), de Lurgio Gavilán Sánchez, traduzida por Jade durante a sua pesquisa de Iniciação Científica (PIBIC), entre 2015 e 2017. Sendo assim, a performance
Soldados desconhecidos tratava basicamente da seguinte questão: em que se diferenciam os "soldados do exército" que cumprem as ordens do Estado dos "soldados do morro" que estão a serviço do crime organizado?

A performance Soldados desconhecidos começa com a chegada de um jovem com sua roupa camuflada e usando um capuz touca ninja (capuz que cobre todo a cabeça, deixando apenas os olhos à mostra). Esse soldado olha cada um dos jovens nos olhos, ora como se quisesse capturá-los, ora como se os conhecesse. Os olhos de Jade - soldado - encaram aos jovens como seus iguais. Em algum momento da performance, este jovem começa a ouvir testemunhos (em áudio) das mães que perderam seus filhos em situações violentas e a partir deste estímulo sensorial o soldado faz um streap tease ao qual denominamos streap tease da contradição. Neste streap tease o soldado tira sua roupa durante um gesto de revelação de sua verdadeira identidade. Ele é um jovem comum, com sonhos, medos que, pouco a pouco, constrói a sua identidade a partir de que vê e sente através do contato com outras pessoas, mas também a partir do que vive em sua realidade, o contexto social que o molda. No centro da sala colocávamos uma caixa com doces e ao "descobrir" esta caixa no cenário, a presença iniciava sua prática de venda dos doces, instaurando no espaço um movimento de apreensão e informalidade que lhes causava curiosidade e estranhamento. 

Soldados Desconhecidos. Oficina de teatro na CASE Salvador, Bahia, Brasil. 24 de novembro de 2016

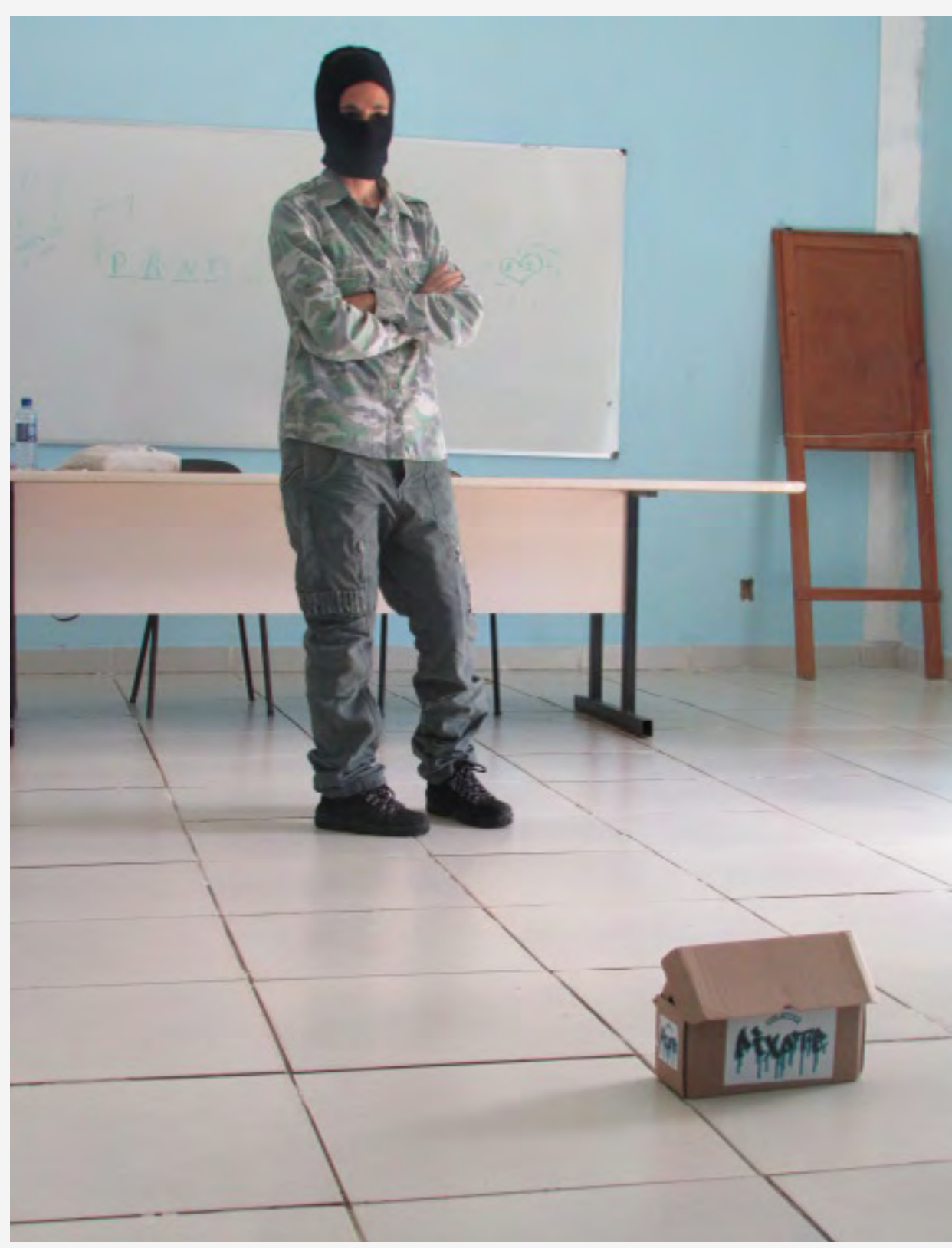

FOTOGRAFIA 2

Nesta performance, após se despir do traje de soldado, Jade usava uma camisa que tinha o rosto de Victor Jara, cantor, poeta, diretor de teatro, professor e ativista político que foi assassinado em 1973, nos primeiros anos do regime ditatorial de Augusto Pinochet, logo após o golpe militar no Chile. A ideia de utilizar a camisa com a foto de Victor Jara era, além de afastar-nos da realidade referente, difundir que a arte é uma ferramenta de resistência ainda quando por ela se dá a vida, como no caso de Victor Jara, que era apresentado aos adolescentes, como este indivíduo que se arrisca para impedir situações de opressão e injustiça. Depois se despir de sua dupla identidade de soldado, e assumir a presença de um jovem vendedor a mbulante, Jade recitava o poema "Los Nadies" (1940), do escritor uruguaio Eduardo Galeano que ela traduziu ao português para facilitar a compreensão dos jovens.

Terminada a sua performance, e depois de se recompor, Jade e eu tratávamos de abrir para a discussão o processo de construção da performance, a partir das especulações dos adolescentes sobre o que viram em cena. Construir o significado da performance juntos, através dos comentários dos jovens tinha como proposta fazê-los pensar que o exercer e o sofrer a opressão estão condicionados aos papéis que cada um pode ocupar na sociedade. Através desse exercício foi possível ta mbém dar visibilidade às narrativas 
29. O Teatro Jornal, segundo Boal, (1971, p. 57-59) tem como primeiro "objetividade" do jornalismo: demonstra que uma notícia publicada em um jornal é uma obra de ficção. [...] Algumas de suas técnicas com a do "improviso" são a realidade mesma: aqui não se trata de representar uma cen mas de vivenciá-la cada vez. [... O segundo objetivo é tornar o teatro mais popular. [...] populariza alguns meios de se fazer teatro - a fim de que o próprio povo deles se possa utilizar, para produzir seu próprio teatro. [...] O terceiro objetivo consiste em demonstrar que o teatro pode ser praticado mesmo por quem não é artista, da mesma maneira que o futebol pode ser praticado por quem não é atleta. Ainda, de acordo com Boal (1971, p. 60), são nove as primeiras écnicas do Teatro Jornal, as quais explicar o funcionam, contudo, uma São 2. Improvisação. 3 Leitura com ritmo. 4. Ação paralela. 5. Reforço. 6. Leitura cruzada. 7. Histórico. 8. Entrevista de Campo 9 . Concreção da abstração $(1971$, p. 60). reais que os jovens sentiam vontade de contar quando conquistáva mos sua confiança, assim eles nos respondiam com o que podemos denominar de "reafectos criativos", isto é das reações que partindo de uma relação afetiva e de cumplicidade, durante as oficinas, propiciou a criação artística.

Na segunda parte da oficina, após a performance Soldados desconhecidos, por exemplo, realizáva mos o jogo que demos o nome de "Meu corre é uma manchete", inspirado no Teatro Jornal, ${ }^{29}$ que é uma das técnicas do Teatro do Oprimido. Neste jogo eles nos narravam, em segredo, uma situação vivida ou testemunhada e nós a encenávamos com gestos, sem utilizar palavras, sem nomear os sujeitos, de modo que, para cada cena, os adolescentes deviam criar títulos e noticiá-las, posteriormente, como se fossem os repórteres. Neste jogo todos participavam, questionando as manchetes, assumindo diferentes papeis e, conduzindo as cenas apresentadas, reconstituindo uma situação real e dando a ela novos desfechos.

Nas oficinas de teatro realizadas na CASE Salvador, quando fazíamos jogos e apresentações introdutórias pedía mos ta mbém para os socioeducadores que se apresentassem e comentassem um pouco sobre quem era, por que estavam ali, quais eram seus sonhos. Esta prática trouxe excelentes resultados, já que todos podiam compartilhar a partir do reconhecimento de suas identidades "quem eram", suas motivações para estarem ali e quais papéis cumpria m. Esta conduta adotada por nós ao longo das oficinas foi uma sinalização de Augusto Boal, ${ }^{30}$ ao expor sua experiência de três a nos com o Teatro do Oprimido praticado com jovens em conflito com a lei. ${ }^{31}$ Naquele contexto, Boal defendia que para que o trabalho produzisse um diálogo pedagógico e não um enfrentamento hostil, deveria incluir todos os integrantes do sistema, não somente os jovens para que todos pudessem ser beneficiados com este diálogo:

É preciso que mostremos que a cada indivíduo, seja qual for sua função dentro desse Sistema, é capaz de pensar alternativas para cada ato que pratica, cada hábito não questionado, cada frase mecanicamente repetida.

Cada jovem é diferente e único; temos que reconhecê-lo na sua unicidade: este é primeiro passo para a afirmação de sua liberdade prisioneira. Cada funcionário tem suas necessidades salariais, familiares, profissionais. Temos que compreendê-las e ajudá-los a expressá-las. ${ }^{32}$

Seguindo estas orientações, abrimos as atividades para que os funcionários das CASE pudessem não somente acompanhar o seu desenvolvimento, qua nto participar delas. Em cada unidade há escolas do município ou do estado que garantem a educação formal dos adolescentes. As oficinas aconteciam em horário paralelo, contudo, as professoras
30. BOAL. O teatro como arte marcial, p. 175

31. O projeto mencionado, segundo Boal (2009, p. 173), tinha o título de Mudança de Cena. Na época Boal, junto ao antigo Degase Departamento Geral de Ações Socioeducativas, à Fundação do Jovem Cidadão, ao Centro de Estudos de Segurança e Cidadania - CESEC e ao Centro do Teatro do Oprimido do Rio de Janeiro - CTO.

32. BOAL. O teatro como arte marcial p.176.

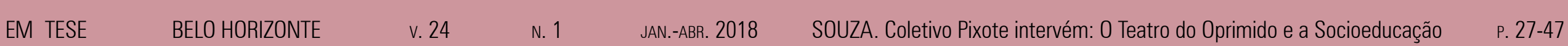


33. BOAL. O teatro como arte marcial, p.178. que atuam neste contexto também se interessava m pelo trabalho que ali realizáva mos e que impactava positivamente os adolescentes, segundo feedbacks que recebíamos informalmente. Estas respostas nos ajudavam a rever atividades cujo nicho pedagógico central residia-se apenas em garantir espaço de fala para os adolescentes e jovens. Assim, durante as oficinas traçáva mos uma linha horizontal entre nós oficineiros, os adolescentes e os funcioná rios das CASE, de modo que desenháva mos no espaço das oficinas, sobretudo nas de tea tro, uma convivência relacional possível, a fim de combater o "enfrentamento imagético", mencionado por Boal: “[...] de um lado, Curingas; do outro adolescentes. Dois grupos com nítidas diferenças e poucas semelhanças. Somos os que vieram de fora, com a carga emotiva do que significa viver lá fora, gozando a liberdade que desejam, se não a têm, ou desejam ampliar, se assistidos". ${ }^{33}$

Entendo que, para os adolescentes este enfretamento mencionado por Boal não é imagético pelo modo como o teatro se realiza e por quem são os Curingas e por quem são eles. Mas, ao traçar esta linha horizontal, ainda que na tensão de um enfreta mento real, estabelecemos as condição do jogo e da simulação que torna possível uma relação de horizontalidade entre os sujeitos que ocupa m aquele espaço, desfazendo os confrontos e aproximando as diferenças naquilo que torna comum os indivíduos: é quando um oficineiro se emociona em cena e isso se faz perceptível; os adolescentes comentam e trazem à tona questões que abrangem a subjetividade do sujeito que está ali para trabalhar, mas é afetado pelas narrativas que ouve, pelos rostos que enxerga; é quando um adolescente oferece o seu pacote de biscoitos aos oficineiros, interrompendo a cena, percebendo que a fome que o afeta é a mesma que afeta o profissional - este pode aceitar e intensificar ainda mais essa linha relacional estabelecida ou não aceitar, agradecendo e mantendo firme esta mesma linha relacional que ao longo dos dias se fortalece, de modo que o "enfrentamento imagético" é desfeito, o diálogo torna-se horizontal e afetivo. No encerramento das oficinas uma certeza: se o adolescente está ali, isso se deve às fragilidades das políticas públicas e ao abandono do Estado. Não é uma escolha sua, mas uma condição. Se nós estamos ali, como coletivo, é uma escolha que reafirma nossa intenção e as motivações que nos levam a encontrá-los, a entendê-los, a identificá-los pelo nome e em suas particularidades e a querê-los bem.

\section{A INTERVENÇÃO NA SOCIOEDUCAÇÃO COMO UM}

\section{TRABALHO EM PROCESSO}

Durante a realização das três oficinas, ao longo da execução do projeto, as principais discussões eram relacionadas à definição de um cronograma de atividades, modificado em 
relação ao projeto inicial, em função da rotina das CASE. Essas definições do cronogra ma estavam condicionadas à disponibilidade da equipe executora, ao calendário de atividade das CASE e da liberação do transporte para o deslocamento dos membros do coletivo. Essas discussões eram conduzidas pelas equipes que administravam as CASE. Já em relação às discussões pedagógicas, ficavam restritas a nós, do Coletivo Pixote e aos membros dos coletivos colaboradores. O debate tinha como pauta a adequação das oficinas ao número de jovens e adolescentes, por exemplo. Nas unidades de Feira de Santana e de Camaçari este número era em torno setenta (70) a oitenta (80). Na CASE que se localiza na cidade de Salvador, assistimos por volta de trezentos e quinze (315) jovens. Sobre este número de adolescentes e jovens em conflito com a lei, alguns já estavam sentenciados (já faziam parte do grupo de jovens em situação de privação de liberdade permanente) e se diferenciavam dos adolescentes que se encontravam em situação de privação de liberdade provisória (eram recém-chegados e se apresentavam indispostos e tímidos em relação às propostas das oficinas, o que entendíamos como resposta ao a mbiente ao qual acabavam de chegar). Estas questões eram discutidas por nós, pois devíamos rever as metodologias utilizadas nas oficinas, adaptando-as de acordo com o perfil da CASE e dos adolescentes. Por exemplo, em virtude da quantidade de jovens, muito maior na Comunidade de
Atendimento Socioeducativo de Salvador, optamos por não apresentar a performance Kilates e criamos uma performance especifica para desenvolver o Tea tro Fórum e o Teatro Jornal e, a partir deles, dialogarmos sobre as diferentes identidades que um "soldado" pode assumir.

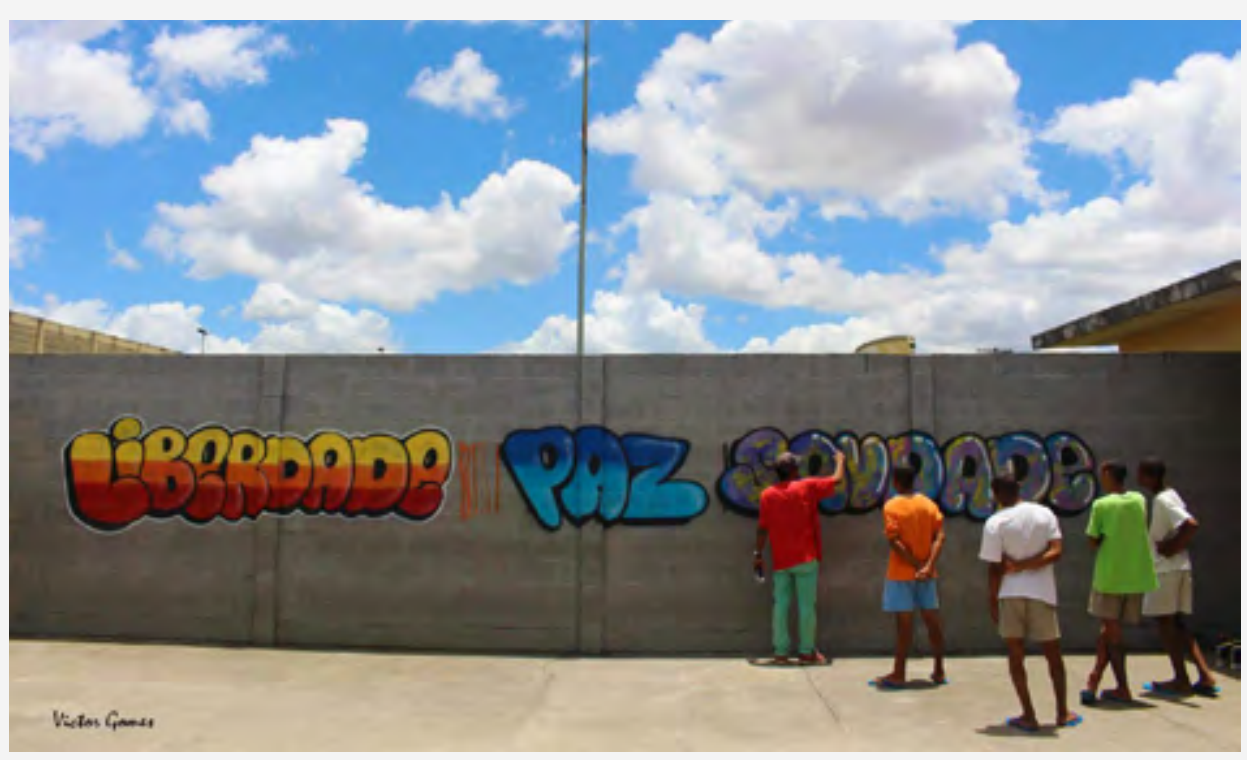

FOTOGRAFIA 3

Durante as oficinas de grafite, conduzidas pelo grafiteiro e artistas visual Zezé Olukemi, foi possível pautar não só as questões técnicas relacionadas às artes visuais, como ta mbém foram consideradas questões complexas acerca dos caminhos que cada jovem trilha na busca do melhor para si mesmo através do efetivo diálogo que se estabelece durante
FOTOGRAFIA 3 Zezé Olukemi e adolescentes da CASE Zilda Arns em Feira de Santan Bahia, Brasil. Oficina de Grafitte. 13 de outubro de 2016

Foto por Victor Gomes. 
a criação dos desenhos, a responsabilidade sobre o que se deve ou não expressar, a diferença entre sujar e macular ou cuidar e enfeitar o lugar onde o indivíduo vive ou habita com as marcas de sua identidade e de seus gostos. Em cada CASE, ficaram registradas as marcas das oficinas, como uma lembrança do que se viveu e aprendeu de forma coletiva. É um resíduo material da passagem do Coletivo Pixote pelas unidades que fica na memória de quem conosco compartilhou estes dias de convivência. Zezé Olukemi, conduzia as oficinas de modo a deixar aos adolescentes a decisão sobre o que grafitar, quais palavras gostariam que estivessem nos muros das CASE ou nos banhos de sol. Na CASE Irmã Dulce, em Camaçari, chamou-nos atenção que os adolescentes de um alojamento pedissem que o jogo da Amarelinha fosse graffitado no banho de sol, segundo um deles "para jogarem dura nte o tempo em que não têm atividades”.

No que refere ao caráter experimental e em processo de nossas propostas pedagógicas, considero que, através das oficinas de criação artística podemos contribuir tanto para com a educação formal dos adolescentes, como para com sua formação artística e cidadã, já que trata mos de temas socioculturais a partir da linguagem artística. Os principais objetivos das ações fora m: a) oferecer oficinas de produção artística para os adolescentes e jovens em regime de privação de liberdade para cumprimento de medidas socioeducativas; b) construir um espaço para a criação artística dos adolescentes e jovens, a partir da reflexão sobre sua realidade e temas curriculares da educação formal; c) contribuir para o processo de ressocialização de adolescentes e jovens que cumprem medidas socioeducativas em regime de privação de liberdade; d) fomentar estratégias de reintegração dos adolescentes e jovens à sociedade através do incentivo em sua educação formal, artística e profissional.

Sobre os objetivos das oficinas, gostaria de destacar brevemente de que maneira cada uma foi pensada: a) nas oficinas de Grafite propomos estimular o interesse dos jovens na produção artístico-visual e a confia nça no trabalho em equipe; b) nas oficinas de Teatro propomos fomentar a apresentação e problematização de situações de opressão através do Teatro do Oprimido e por meio da criação de um sistema ético de convivência entre os adolescentes e jovens, oficineiros e funcionários das unidades, no qual estes foram estimulados a criar e mobilizar suas reflexões através da performatividade dos comportamentos e discursos; c) nas oficinas de Freestyle - ritmo e poesia, nossos objetivos foram colaborar e incentivar a criação/produção escrita e oral de textos poéticos improvisados.

As oficinas oferecidas e conduzidas pelos membros fixos e colaboradores do Coletivo Pixote contribuíram, sem 
dúvidas, para o desenvolvimento da autoestima dos jovens e de suas habilidades intelectuais e físicas. Assim mesmo, considero que outros sujeitos foram afetados por nossa presença. Durante a realização das oficinas contáva mos com a participação dos agentes socioeducativos e dos agentes de segurança. A presença dos agentes socioeducativos e dos agentes de segurança que lidam diariamente com os jovens nos pareceu, a princípio, desafiadora, já que representam a autoridade dentro do lugar e deviam exercer uma função vigilante e, se necessário, preventiva, pois monitoravam comportamentos e discursos que circulavam no contexto do desenvolvimento das atividades. Nas primeiras oficinas, a presença destes profissionais nos fez questionar até que ponto os adolescentes responderiam às propostas de criação de modo espontâneo, sem censuras. Sentimos que a presença desses profissionais poderia representar um limite para sua criatividade mais orgânica. Mas, no transcurso das oficinas entendemos que a melhor maneira de romper com este limite era convidá-los e envolvê-los nas atividades, fazê-los interagir nas atividades, em outras situações que não as cotidianas, próprias do espaço de convivência comum.

Ao se envolver em situações teatrais, os adolescentes jovens desenvolveram estratégias de superação a través da criatividade. Essas estratégias se dão no exercício de reviver situações passadas relacionadas ou não aos motivos que os levaram às CASE; é ta mbém um exercício de rever as ações com outros olhos, de expô-las em um contexto distinto daquele que caracteriza o "flagrante" e os julgamentos aos quais estão submetidos. Os adolescentes e jovens, embora pudessem falar de outros assuntos nas oficinas de Teatro preferiam falar sobre a violência (de modo geral) ou sobre seus próprios atos infracionais e opressões vividas, de modo que estes foram os temas mais abordados durante a realizacão dos fóruns. Porém, em um dos fóruns, dura nte as oficinas de Tea tro realizadas na CASE Zilda Arns, por sugestão de uma pedagoga da FUNDAC, encenamos uma situação de fuga, isto é, de uma infração cometida dentro do sistema socioeducativo. A funcionária da FUNDAC narrou que um grupo de adolescentes tinha que se deslocar da CASE, onde cumpriam suas medidas socioeducativas até uma sede bancária, onde abririam contas. No entanto, a pedagoga termina seu relato dizendo que, apesar da confiança depositada no grupo, no contexto do desloca mento um dos adolescentes fugiu, dando início a uma perseguição em perímetro urbano e colocando os demais adolescentes e profissionais que os acompanhavam em uma situação de insegurança pública. Uma vez apreendido, ela diz que o adolescente sofreu a sanção que lhe cabia. Ao narrar a situação para os adolescentes e jovens presentes na oficina, a pedagoga instaurou um tema de complexo debate, já que, os adolescentes e jovens

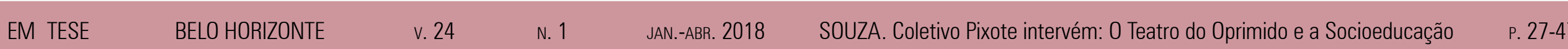


34. Nome fictício

35. Nome fictício. ali presentes "contam" os dias para estarem em liberdade, sendo assim: o que seriam capazes de fazer para alcançar, de modo mais imediato, a sua liberdade?

Por escolha dos adolescentes, o foco da improvisação partir do fato relatado não foi dado à fuga, mas ao momento de apreensão do adolescente: qual havia sido sua sanção? $\mathrm{O}$ que o adolescente disse ao ser interrogado sobre por que desobedeceu a confiança que lhe fora depositada? Posso dizer que, tendo presenciado várias improvisações, as que fora $\mathrm{m}$ realizadas em torno deste fato fora $\mathrm{m}$ as mais interessantes, já que os dois adolescentes Vitor ${ }^{34}$ e Cristiano, ${ }^{35}$ que quiseram ocupar o lugar do colega que decidiu fugir apresentaram suas motivações a mparados por argumentos que partiam de sua subjetividade, alegando razões emocionais como a "saudade da família", a "saudade da mãe", mas, principalmente, por estarem "com a mente apertada" devido ao confinamento e terem vislumbrado "o mundão" como uma "chance de ser outra pessoa". Uma vez que nenhum dos dois havia estado em tal situação, os motivos pelos quais justificaram sua fuga, (que podem ser bem diferentes dos motivos que levou o adolescente a fugir, na situação real) ao assumirem o papel do colega, na representação, podem ser vistos como os motivos pelos quais desejavam estar em liberdade. Desse modo, menos que abordar a sanção dada ao adolescente, suas (possíveis) motivações para fugir foram destaque e sua ação, embora reprovável, foi honestamente justificada na visão dos atores e dos espect-atores.

\section{CONSIDERAÇÕES FINAIS}

Ao longo de um semestre foram ministradas oficinas de criação artística aos adolescentes em situação de privação de liberdade e cumprimento de medidas socioeducativas de internação (definitivas ou provisórias) em Salvador, Camaçari e Feira de Santana. Nas oficinas de teatro os jovens puderam participar de performances, de atividades relacionadas ao reconhecimento do corpo do ator e do espect-ator e criaram micro cenas cujas narrativas tinham como base fatos reais vividos por eles ou situações por eles testemunhadas. Nas oficinas de Graffite e Freestyle, trabalhamos com a improvisação, a partir de suas experiências, com a produção de artes visuais (graffite) e dos poemas improvisados (RAP). Aproximadamente 450 adolescentes participaram das oficinas, sendo possível crer que lhes proporcionamos a possibilidade de estabelecer um diálogo entre seu presente de reclusão e suas expectativas futuras de recomeçar uma nova vida, quem sabe, buscando na arte um modo de expressar seus medos e sonhos.

Com relação aos estudantes de Letras envolvidos neste projeto, para eles as oficinas foram um espaço de promoção de diálogos entre as a tividades acadêmicas nas quais estão envolvidos, a militância aplicada e o ativismo crítico, no 
36. DAVIS. Democracia de la abolición. Prisiones, racismo y violencia, p. 108

37. Da fonte: “[...] la creación de nuevas instituciones que reclamen el espacio que ahora ocupa la prisión". A tradução para o português foi feita pela autora. $O$ mesmo sobre as três seguintes notas. In: DAVIS. Democracia de la abolición. Prisiones, racismo y violencia, p. 108.

38. "[...] puedan verse, por tanto como la alternativa más poderosa a las cárceles y prisiones".

In. DAVIS. Democracia de la violencia, p. 108

39. “[...] se conviertan en lugares que alientan el ánimo de aprender". In: DAVIS. Democracia de la abolición. Prisiones, racismo y violencia, p. 108

40. “[...] vehículos para reducir el número de presos". In: DAVIS. Democracia violencia, p. 108.

FOTOGRAFIA 4

Cíntia Savoli, Mira Potira e DJ

CASE Salvador, Bahia Brasil. 25 de

novembro de 2016.

Foto: Lindy Santos. âmbito dos Direitos Humanos, a partir da socioeducacão e da intercessão das diferentes disciplinas.

Dessa experiência ficou para nós, do Coletivo Pixote, pensarmos com Angela Davis, ${ }^{36}$ que uma proposta de es vaziar a prisão ou, no caso dos adolescentes e jovens, as Comunidades de Atendimento Socioeducativas (embora sigam uma abordagem socioeduca tiva, reproduzem o modelo físico e os imaginários da prisão feita para os adultos) seja "a criação de novas instituições que ocupem o espaço que agora ocupa a prisão", ${ }^{37}$ entre elas, as escolas que "podem ser vistas, portanto, como a alterna tiva mais poderosa aos cárceres e prisões" 38 desde que "convertam-se em lugares que estimulem o ânimo de aprender" ${ }^{39}$ e se transformem em "veículos para reduzir o número de presos".

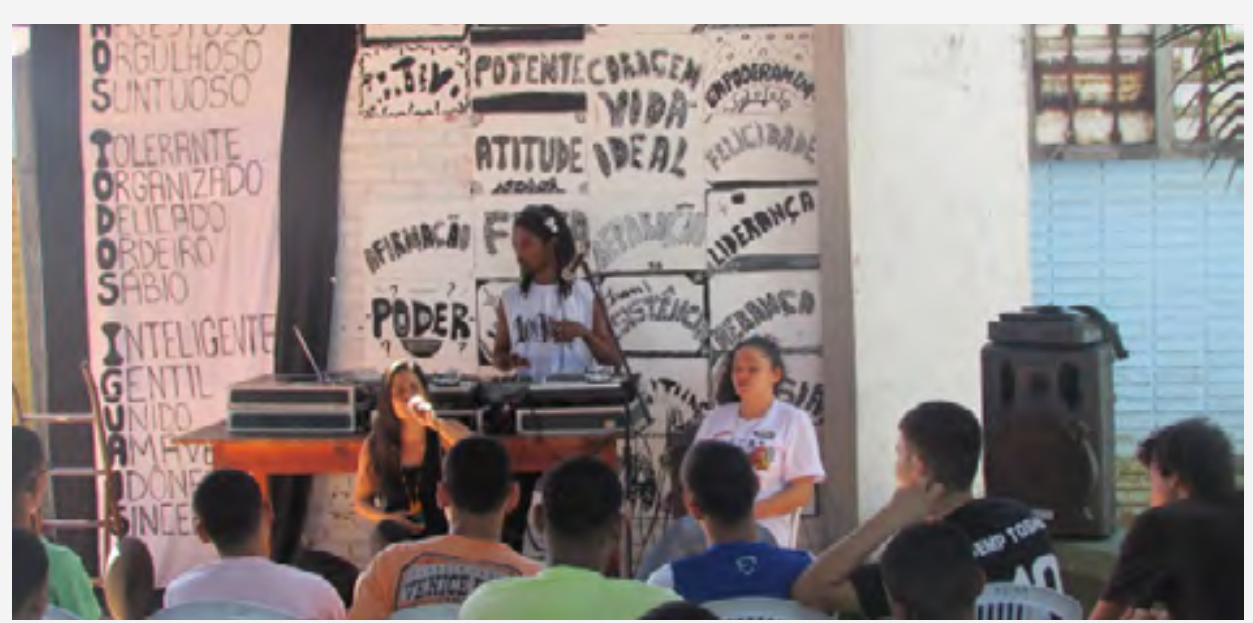

FOTOGRAFIA 4
Ao longo das oficinas de teatro (utilizando o Teatro do Oprimido, realizadas nas três comunidades, os estuda ntes que a tuaram no projeto e que estiveram sob a minha orientação puderam propor e discutir reflexões sobre a relação entre seus estudos sobre a performance e a sua prática, como uma obra aberta às interferências do público e à sua transformação. Além disso, nas demais oficinas, também o caráter performático esteve presente: na escritura visual do grafite, na improvisação e composição de letras de RAP que servem para contar histórias, narrar experiências e denunciar.

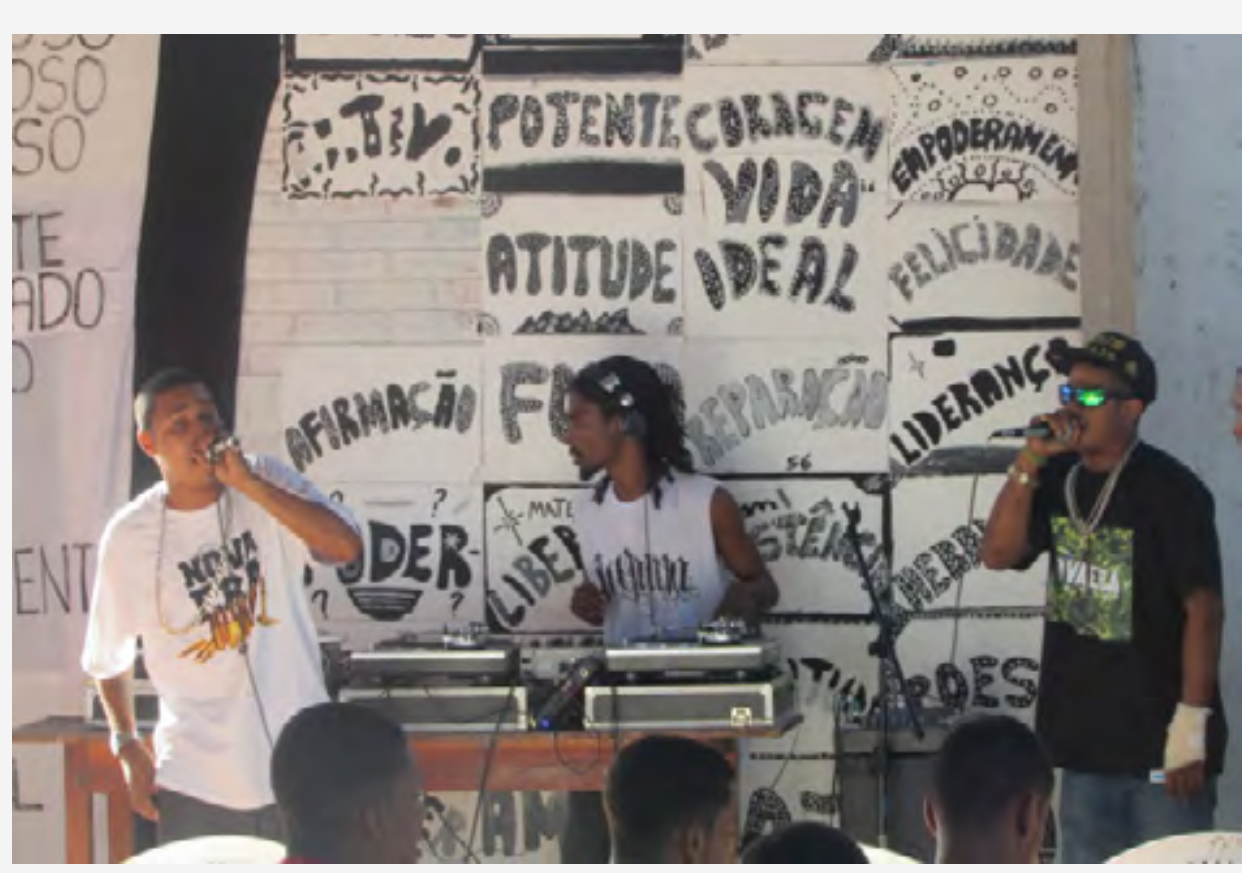

FOTOGRAFIA 5
FOTOGRAFIA 5 Fotografia 5. MC Ravi Lobo, MC Mrojeto CASE Salvadorramento do T5 de nove Salva Bahia, Brasil. Foto de Lindy Santos.
EM TESE 
Acredito que a escola pode prevenir e combater a prática de atos infracionais e também o racismo e outras práticas excludentes, desde que nós, como educadores, esteja mos orientados por uma abordagem socioeducativa. É nesse sentido que organiza mos, como Coletivo, nossas oficinas. Leva mos às CASE uma proposta político-pedagógica que questiona o próprio espaço, propõe uma reflexão sobre de que modo e por quais razões cada um ocupa este lugar, a fim de transformá-lo em um espaço em que o acolhimento, a convivência, a superação de conflitos internos e a autoestima dos sujeitos sejam trabalhados, seja m valorizados. Assim, o Coletivo Pixote, atuando com os agentes que fazem parte do sistema socioeducativo intervém com o propósito de aprender e sinalizar, dentro deste espaço, uma possibilidade de mudança para aqueles jovens que por sua condição étnica e de classe, tiveram que escolher outros caminhos.

\section{REFERÊNCIAS}

BISINOTO, Cynthia; OLIVA, Olga Brigite; ARRAES, Juliana; GALLI, Carolina Yoschii; AMORIM, Gustavo Galli, e STEMLER, Luana Alvez de Souza. Socioeducação: origem, significado e implicações para o atendimento socioeducativo. Maringá. Psicologia em Estudo. Maringá. Departamento de Psicologia da Universidade Estadual de Maringá. V. 20. N. 4. p. 575-585, out./ dez. 2015. Disponível em: <http://www. periodicos uem.br/ojs/ (index.php/ PsicolEstud/article/view/ 284 56>. Acesso em 09 de abril de 2018.
BOAL, Augusto. Teatro Jornal. Primeira edição. In: BOAL, Augusto. Categorias do Teatro Popular. São Paulo: Teatro Arena, 1971. p. 57-71. Arquivo Digital disponível em: <https:// institutoaugustoboal.files.wordpress.com/2017/05/teatrojornal1-1. pdf $>$. Acesso em 30 de março de 2018.

BOAL, Augusto. $\mathbf{O}$ Teatro como arte marcial. Rio de janeiro Garamond. 2009

BOAL, Augusto. Jogos para atores e não atores. Tradução de Barbara Wagner Mastrobueno e Célia Euvaldo. São Paulo: Cosac Naify, 2015.

Brasil. Estatuto da criança e do adolescente. Estatuto da criança e do adolescente e legislação correlata [recurso eletrônico]: Lei n. 8.069, de 13 de julho de 1990, e legislação correlata. - 12 ed. - Brasília : Câmara dos Deputados, Edições Câmara,- (Série legislação ; n. 122). Disponível em: <http://www2.camara.leg. br/a-camara/programas-institucionais/inclusao-social-eequidade/ acessibil idade/legislacao-pdf/estatuto-da-crianca-e-doadolescente. >Acesso em 10 de abril del 2018.

BUTLER, Judith. Quadro de Guerra. Quando a vida é passível de luto? Traducão de Sérgio Lamarão e Arnaldo Marques da Cunha. Rio de Janeiro: Civilização Brasileira, 2015.

CAMARGOS, Roberto. RAP e política. Percepções da vida social brasileira.São Paulo: Boitempo, 2015. 
CERQUEIRA et al. Atlas da Violência 2017. Rio de Janeiro: Instituto de Pesquisa Econômica Aplicada (IPEA) e pelo Fórum Brasileiro de Segurança Pública (FPSP), 2017. Disponível em: $<$ http://infogbucket.s3.amazonaws.com/arquivos/2016/03/22/ atlas_da_violencia_2016. pdf $>$. Acesso em 20 de abril de 2018.

DAVIS, Angela Y. Alternativas Abolicionistas. In: DAVIS, Angela Y. Democracia de la abolición. Prisiones, racismo y violencia. Edición de Eduardo Mendieta. Traducción de Irene Fortea. Madrid. Trotta Editoral, 2016. p. 106-114.

MUNIZ, Mariana Lima. Improvisação como espetáculo.

Processo de criação e metodologias de treinamento do atorimprovisador. Belo Horizonte: Editora UFMG, 2015.

SILVA, Enid Rocha Andrade da; OLIVEIRA, Raissa Menezes de Oliveira. O Adolescente em Conflito com a Lei e o Debate sobre a Redução da Maioridade Penal: esclarecimentos sobre a Redução da Maioridade Penal: esclarecimentos

necessários. Brasília: Instituto de Pesquisa Econômica Aplicada images/stories/PDFs/nota_tecnica/150616_ntdisoc_n20 > . Acesso em 05 de agosto de 2018

SPOLIN, Viola. Jogos teatrais na sala de aula: o livro do professor. Tradução de Ingrid Dormien Koudela. São Paulo: Perspectiva, 2007

Recebido em: 10-06-2018

Aceito em: 02-09-2018 